\title{
CAN WE BEAT THE "BUY-AND-HOLD" STRATEGY? ANALYSIS ON EUROPEAN AND AMERICAN SECURITIZED REAL ESTATE INDICES
}

\author{
Eddie C. M. HUI ${ }^{a, *}$, Sheung-Chi Phillip YAM ${ }^{\text {b }}$ \\ ${ }^{a}$ Department of Building and Real Estate, The Hong Kong Polytechnic University, Hung Hom, Kowloon, \\ Hong Kong, China \\ ${ }^{b}$ Department of Statistics, The Chinese University of Hong Kong, Hong Kong, China
}

Received 30 January 2012; accepted 19 November 2012

\begin{abstract}
The aim of this paper is to use the Shiryaev-Zhou index to examine the performances of securitized real estate indices of four countries: US, UK, Canada and Germany. The result reveals that the Shiryaev-Zhou index is a leading indicator and can act as a predictor on certain securitized real estate indices. Furthermore, our results show that the trading strategy we constructed according to the Shiryaev-Zhou index generally outperforms the "buy-and-hold" strategy under the assumption of no transaction costs. The stronger the predictive power of the Shiryaev-Zhou index is, the larger extent our trading strategy beats the "buy-and-hold" strategy. This is useful in strategic property management that property practitioners can follow our strategy to trade real estate stocks/funds in order to increase their profits.
\end{abstract}

KEYWORDS: Securitized real estate index; Shiryaev-Zhou index; "Buy-and-hold"; Trading strategy; Granger-causality test

REFERENCE to this paper should be made as follows: Hui, E. C. M.; Yam, S.-C. P. 2014. Can we beat the "buy-and-hold" strategy? Analysis on European and American securitized real estate indices, International Journal of Strategic Property Management 18(1): 28-37.

\section{INTRODUCTION}

To maximize profit is the common objective for many investors. A commonly known trading strategy is the "buy-and-hold" strategy, i.e. one should buy a stock and hold it for a long time. The "buyand-hold" strategy is based on the efficient market hypothesis (EMH). However, this hypothesis may not be true. Hence some people look for a strategy to beat the "buy and hold" strategy. There have been studies on portfolio return optimization for long. The first of such studies was done by Markowitz (1952), who introduced the meanvariance modern portfolio theory (MPT). Hui et al. (2009) incorporated expert knowledge into MPT through fuzzy set theory to obtain portfolio return optimization in direct real estate investment.

Consider the following problem: a person buys a stock at a time and must sell it within a certain

\footnotetext{
* Corresponding author. E-mail: eddie.hui@polyu.edu.hk
}

period of time, say, one year. What is the optimal time to sell the stock? It would be ideal if one can sell the stock exactly at the maximum price over the period. Unfortunately, this is impossible as we can only know the time the stock price reaches the maximum at the end of the period. Here is a more sensible problem: to minimize the expected relative error between the selling price and the maximum price.

Graversen et al. (2001) took a first step to analyze similar problems along this direction. They solved the problem to stop a Brownian motion so as to minimize the square error deviation from the maximum. Later, Shiryaev (2002), after whom the Shiryaev-Zhou index was named, investigated the quickest detection problem for a change of market parameters, while Li and Zhou (2006) revealed the high chance of a Markowitz mean-variance strategy hitting the expected return target. Shiryaev 
et al. (2008) developed the Shiryaev-Zhou index to determine the optimal time to buy and sell a stock in order to minimize the average relative error of selling price to maximum price. Meanwhile, Du Toit and Peskir (2009) provided a probabilistic proof of the result. Yam et al. (2008, 2009, 2012, 2013) resolved the same problem in the binomial tree setting and hence generalize the ShiryaevZhou index over the corresponding framework. The name of the index is attributed to its two founders, A. Shiryaev and X. Y. Zhou.

The Shiryaev-Zhou index was the first to put in practice by Hui et al. (2012) through a numerical application in the Hong Kong property market. However, they just listed the latest selling date of each real estate stock, but did not calculate the resulting profit. The following question remains: does the Shiryaev-Zhou index really yield a trading strategy which can beat the "buy-and-hold" strategy? This is the advantage of using Shiryaev-Zhou index that we try to illustrate. Here we use the Shiryaev-Zhou index to construct a trading strategy, and apply this trading strategy to real estate markets of different countries, and see whether this strategy can outperform the traditional "buyand-hold" strategy. This would be useful for investors to formulate a better trading strategy to increase their profits.

In order to study real estate markets, we have to choose appropriate real estate indices. Most traditional real estate indices are constructed from real transaction prices recorded in the market (Chau et al. 2005). Two of the examples are the Centa-City Leading Index and the BRE Index (Hui, Wong 2004), the index was later applied by Wong and Hui (2005). However, the observations of these traditional indices cannot be done continuously. There is always time lag between price change and observation. Stock prices, on the other hand, can reflect the values of the companies continuously. Hence they are better than traditional real estate indices. Recently, research workers used econometric methods to study relationship between real estate and stock markets. For example, Okunev and Wilson (1997) tested the existence of co-integration between the REIT and the S\&P 500 indices. The results indicated that the real estate and stock markets were fractionally integrated. Okunev et al. (2000) conducted both linear and nonlinear causality tests on the US real estate and the S\&P 500 indices and concluded that there existed unidirectional relationship from real estate to stock market when using the linear test, but there was a strong unidirectional relationship in the opposite direction when using the nonlinear test. Knight et al. (2005) constructed models of asymmetric dependence using the copula function to examine the relationship between securitized real estate and equity markets. They found that for both U.K. and global markets, the securitized real estate and equity markets exhibited strong tail dependence - particularly in the negative tail, suggesting that real estate securities offer, at best, limited diversification protection when other asset markets were falling. Zhou (2010) applied the wavelet analysis to examine the comovement among international securitized real estate markets and the cross-market comovement between the stock and securitized real estate markets. Rehring and Sebastian (2011) used VAR models to examine the term structure of return volatility of UK and US direct and securitized commercial real estate markets. They found that returns of US REIT, UK direct real estate and property shares exhibited strong mean reversion, while US direct real estate returns show a considerable mean aversion effect over short investment horizons. Hui et al. (2011) examined the relationship between real estate and stock markets in the UK and Hong Kong by the method of data mining. They found not only a positive correlation, but also a co-movement, between the two markets. Moreover, a number of studies showed a long-term positive correlation between real estate and stock prices (Quan, Titman 1999; Tse 2001; Liow 2006). The above results suggest that the stock price can be a leading indicator of the real estate price. Therefore, as an alternative, the indices we used are securitized real estate indices which have a daily frequency. Thus they can reflect the continuous change of value, rather than chasing after the prices.

Our objective is to examine the Shiryaev-Zhou indices of securitized real estate indices of four countries in Europe and North America: US, UK, Canada and Germany, and to verify whether the trading strategy we construct using the ShiryaevZhou index can beat the "buy-and-hold" strategy. The paper proceeds as follows: in Section 2, we briefly describe the formula of the Shiryaev-Zhou index. The statistical method of estimating the Shiryaev-Zhou index is given in Section 3. The behaviour of the Shiryaev-Zhou index of securitized real estate markets of the four European-American countries is given in Section 4. Section 5 explores the relationship between each securitized real estate index and its corresponding Shiryaev-Zhou index. In particular, we test whether the ShiryaevZhou index is a leading indicator of its correspond- 
ing securitized real estate index, and examine the predictive power of the Shiryaev-Zhou index. In section 6 , we compare the resulting return from trading the securitized real estate indices of the four countries by two different strategies: the first strategy is formulated according to the ShiryaevZhou indices of the securitized real estate indices, while the second strategy is the "buy-and-hold" strategy. We consider two cases: without transaction costs and with transaction costs. Finally, a conclusion is drawn in Section 7.

\section{THE SHIRYAEV-ZHOU INDEX}

The Shiryaev-Zhou index is derived by considering the problem of minimizing the gap between the selling price and the maximum price of the stock:

$$
V^{*}=\max _{0 \leq \tau \leq T} \mathrm{E}\left[\frac{S_{\tau}}{S_{T}}\right],
$$

where: $T>0 ; E$ denotes expectation; and $S_{T}=\max _{0 \leq s \leq t} S_{s}$ is the maximum of the stock price.

For simplicity, we assume that the continuously compounded annual interest rate, $r=0$ in this paper. The Shiryaev-Zhou index is defined as (Yam et al. 2008, 2009, 2012, 2013; Hui et al. 2012):

$$
\mu=\left(\alpha-0.5 \sigma^{2}\right) / \sigma^{2}=\alpha / \sigma^{2}-0.5,
$$

where: $\alpha$ is the annual drift or the growth rate of the stock; and $\sigma$ is the annual volatility of the stock ( $\alpha, \sigma$ are constants). The optimal selling time is determined by a simple strategy. If the Shiryaev-Zhou index is positive then the stock should be kept until the end of the period [0,T]. Otherwise it should be sold immediately (Hui et al. 2012).

\section{THE STATISTICAL METHOD OF ESTIMATING THE SHIRYAEV-ZHOU INDEX}

In the formula of the Shiryaev-Zhou index (2.2), the drift $\alpha$ and the volatility $\sigma$ are constants. However, in reality, these parameters can never be constant. Most importantly, we normally do not know the exact values of $\alpha$ and $\sigma$. Here we use the moving window approach to estimate their values: for each day $i(i>n)$, we use the stock prices from day $i-n=1$ to day $i$ to estimate the values of $\alpha$ and $\sigma$ on that day, and hence obtain the estimated value of the Shiryaev-Zhou index on day $i$.

To facilitate the statistical estimation of Shiryaev-Zhou index, $\log \left(S_{t}\right)$ is first transformed into relative ratio $u_{i}(i \geq 2)$

$$
u_{i}=\log \left(\frac{S_{i}}{S_{i-1}}\right),
$$

and hence $u_{i}=\log \left(S_{i}\right)-\log \left(S_{i-1}\right), u_{i}$ can be regarded as the daily return of the stock on day $i$.

Hence the mean of daily return of the stock on day $i(i>n)$ can be estimated by:

$$
\bar{u}_{i}=\frac{1}{n} \sum_{j=1}^{n} u_{i-n+j} .
$$

Here we set $n=130$.

The estimator of $\alpha$ on day $i$ is simply $\bar{u}_{i}$ multiplied by the number of trading days in one year, which we assume to be 250 days:

$$
\hat{\alpha}_{i}=250 \bar{u}_{i} .
$$

Besides the drift term, we also estimate the daily variance on day $i(i>n)$ by:

$$
s_{i}^{2}=\frac{1}{n-1} \sum_{j=1}^{n}\left(u_{i-n+j}-\bar{u}_{j}\right)^{2} .
$$
$i$ is:

Consequently, the estimator of the variance $\sigma^{2}$ on day

$$
\hat{\sigma}_{i}^{2}=250 s_{i}^{2}
$$

and the estimator of the Shiryaev-Zhou index $\mu$ on day $i$ is:

$$
\hat{\mu}_{i}=\frac{\hat{\alpha}_{i}-0.5 \hat{\sigma}_{i}^{2}}{\hat{\sigma}_{i}^{2}} .
$$

\section{SHIRYAEV-ZHOU INDEX OF SECURITIZED REAL ESTATE INDICES OF DIFFERENT COUNTRIES}

Here we analyze the Shiryaev-Zhou indices of securitized real estate indices of four countries in Europe and North America. We select two major economies, UK and Germany, in Europe, and two major economies, US and Canada, in North America. We examine the behaviour of the indices of those countries from time to time. The data of the following securitized real estate indices of the four different countries are obtained from Bloomberg:

1. US: S\&P 500 Building Index;

2. UK: FTSE 350 Real Estate Index;

3. Canada: S\&P/TSX Real Estate Index;

4. Germany: Prime Construction PERF Index.

All the above indices are comprised of stocks of real estate companies, and hence can reflect the performances of real estate markets of the corresponding countries. The period of observation is from January 2, 1990 to April 28, 2009. 
For each securitized real estate index, we use the formula (3.6) to estimate the Shiryaev-Zhou index on each day in the period of observation. Figs 1 to 4 show the trends of Shiryaev-Zhou indices of securitized real estate indices of the four countries over the period of observation.

Table 1 shows the descriptive statistics of the Shiryaev-Zhou indices of securitized real estate indices of the four countries.

From Figs 1 to 4, we can see that the ShiryaevZhou indices of the securitized real estate indices of the four countries followed a similar trend over a certain period of time. For example, the ShiryaevZhou indices of securitized real estate indices of most countries remained negative since late 2007, when the subprime mortgage crisis broke out and caused a global economic recession in the following year, showing that the crisis affected most of the countries. If we get a closer look at the Shiryaev-Zhou indices of securitized real estate indices of US, UK and Canada, we find that their trend had some similarities: the indices peaked in 1993, 1996-1997 and 2003-2004, and reached troughs in 1990, 1994 and 1998-1999. These countries are traditional economies, so their indices behaved normally. The Shiryaev-Zhou index of Germany's securitized real estate index behaved differently from the other three countries that the local events had a greater impact on the Shiryaev-Zhou index than the global events. From late 1995 to early 1996, Germany suffered from an unusually cold weather, causing a lot of deaths and substantial economic loss, so its securitized index fell sharply. Hence its Shiryaev-Zhou index plunged to a record low of -176.42 . On the other hand, global events had a smaller effect on Germany's Shiryaev-Zhou index. Even though the global financial crisis occurred in 2008, the magnitude of negativity of the index was relatively small at that time.

From Table 1, we can see that US's securitized real estate index is the most stable among the four indices, as its Shiryaev-Zhou index has the smallest standard deviation of 16.56. Canada's securitized real estate index is also rather stable. The standard deviation of its Shiryaev-Zhou index is 25.96. The securitized real estate indices of UK and Germany are more volatile, as their Shiryaev-Zhou indices range from over 100 to below -100 , and have a standard deviation of over 30 . In comparison, the securitized real estate markets in North America are more stable than those in Europe.

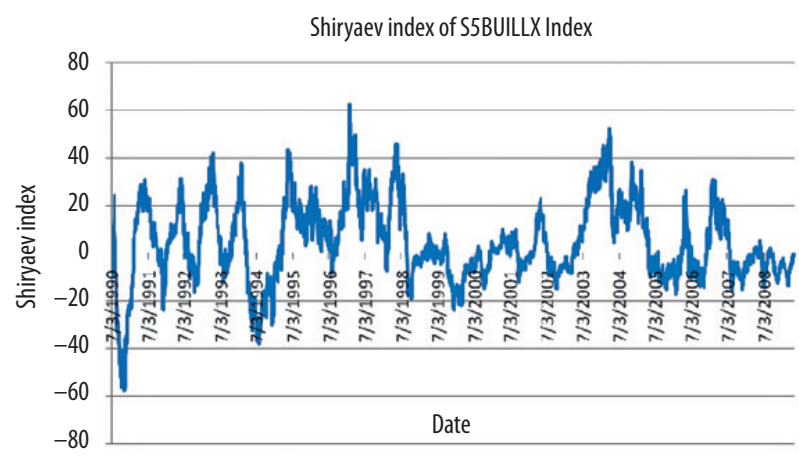

Fig. 1. Shiryaev-Zhou index of US's securitized real estate index

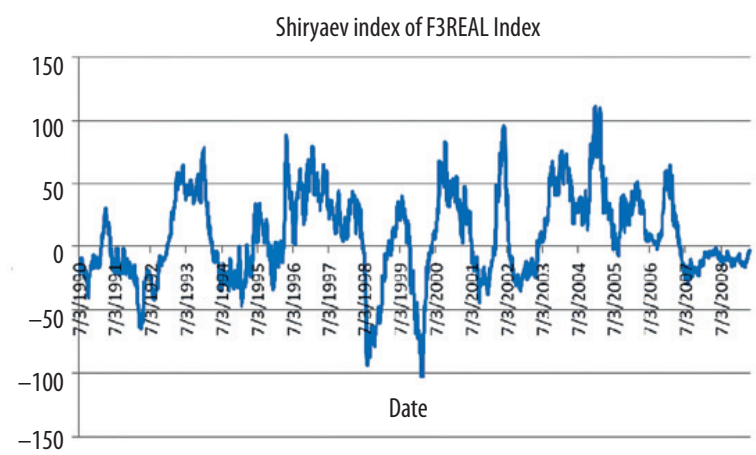

Fig. 2. Shiryaev-Zhou index of UK's securitized real estate index

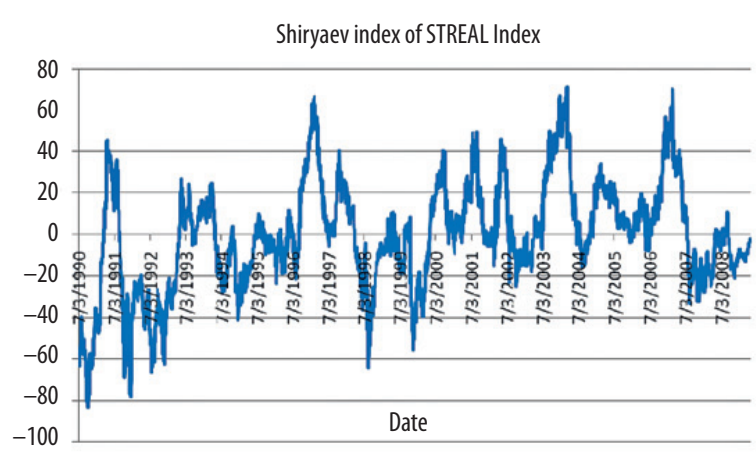

Fig. 3. Shiryaev-Zhou index of Canada's securitized real estate index

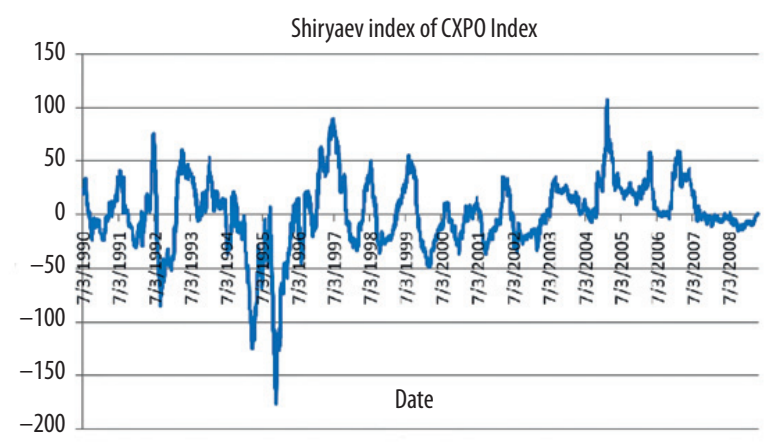

Fig. 4. Shiryaev-Zhou index of Germany's securitized real estate index 
Table 1. Descriptive statistics of the Shiryaev-Zhou indices of securitized real estate indices of the four countries

\begin{tabular}{lllll}
\hline Country & US & UK & Canada & Germany \\
\hline Maximum & 62.66 & 110.92 & 71.07 & 106.72 \\
Minimum & -57.83 & -102.94 & -83.45 & -176.42 \\
Mean & 4.65 & 8.57 & -0.48 & 0.55 \\
Standard deviation & 16.56 & 34.34 & 25.95 & 32.37 \\
\hline
\end{tabular}

\section{RELATION BETWEEN EACH SECURITIZED REAL ESTATE INDEX AND ITS CORRESPONDING SHIRYAEV-ZHOU INDEX}

This section explores the relationship between each securitized real estate index and its corresponding Shiryaev-Zhou index. In particular, the predictive power of the Shiryaev-Zhou index is investigated.

Figs 5 to 8 show the cross correlation function (CCF) between each securitized real estate index and its corresponding Shiryaev-Zhou index. Since the values of Shiryaev-Zhou index in the first 130 days (January 2, 1990 to July 2, 1990) are not available (see Section 3), the first 130 observations of each corresponding securitized real estate index are removed so that the two time series have the same length. Figs 5 to 8 show the results preformed by the online software Wessa (2012). In each figure, Lag (k) denotes the number of days the securitized real estate index lags behind its corresponding Shiryaev-Zhou index.

In all the four figures, $\mathrm{CCF}>0$ for $k=0$, showing a positive (but weak) correlation between the securitized real estate index and its corresponding Shiryaev-Zhou index for all four countries. As k reaches its minimum, $\mathrm{CCF}$ also attains the minimum, showing that for all four countries, it is least likely that the Shiryaev-Zhou index lags behind its corresponding securitized real estate index.

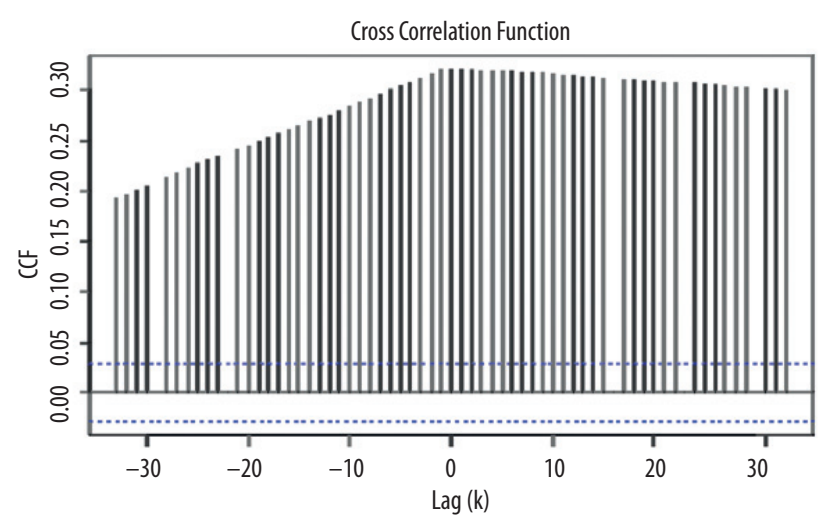

Fig. 5. CCF between US's securitized real estate index and its corresponding Shiryaev-Zhou index

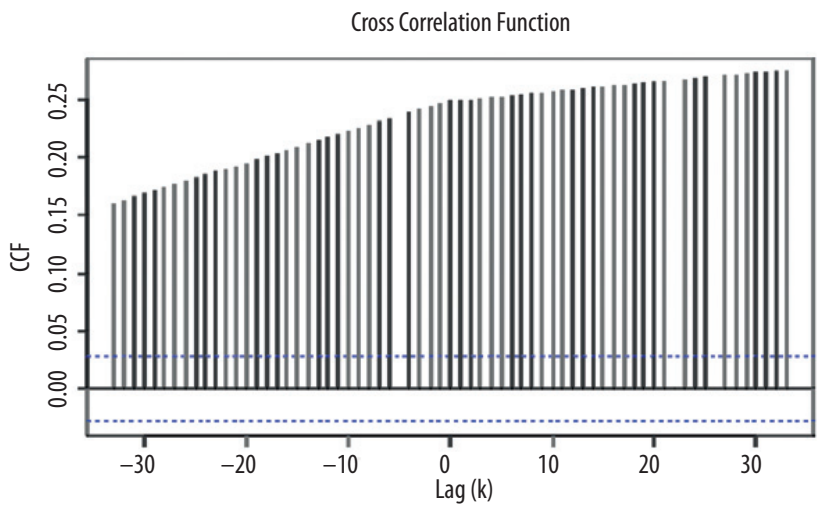

Fig. 6. CCF between UK's securitized real estate index and its corresponding Shiryaev-Zhou index

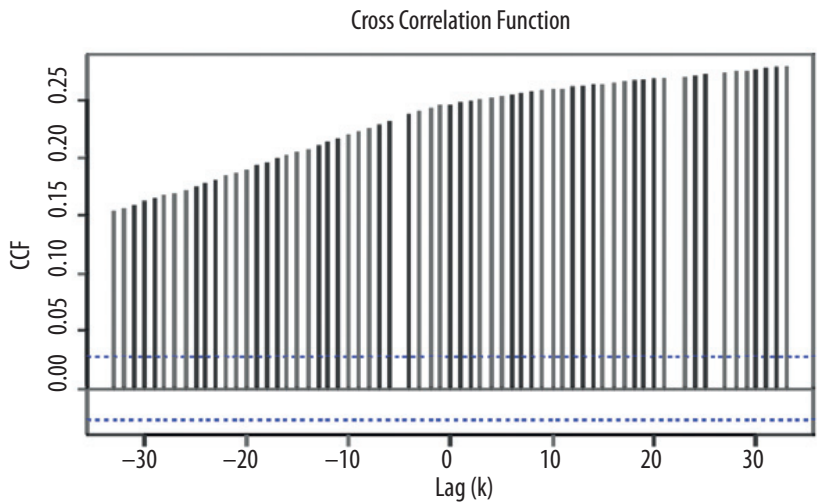

Fig. 7. CCF between Canada's securitized real estate index and its corresponding Shiryaev-Zhou index

Cross Correlation Function

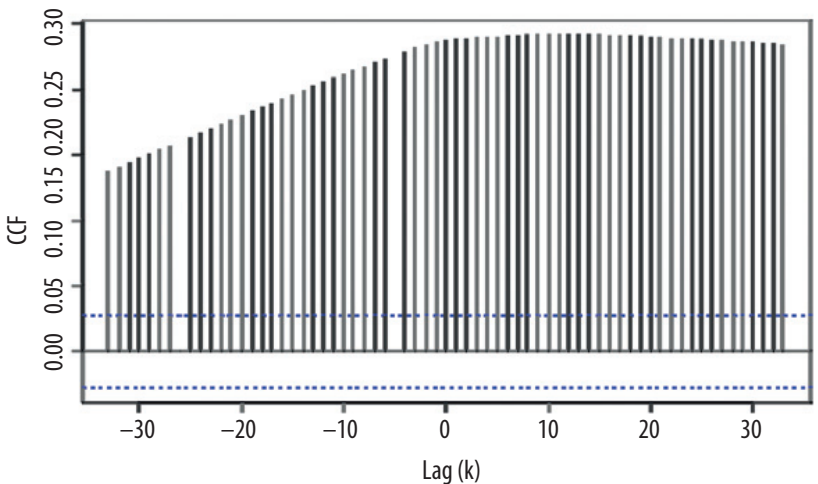

Fig. 8. CCF between Germany's securitized real estate index and its corresponding Shiryaev-Zhou index 
Table 2. The result of the Granger causality test

\begin{tabular}{lllllllllllllll}
\hline $\begin{array}{l}\text { Number of non- } \\
\text { seasonal time lags } \\
\text { in test }\end{array}$ & 1 & 2 & 3 & 4 & 5 & 6 & 7 & 8 & 9 & 10 & 11 \\
\hline $\begin{array}{l}\text { P-value } \\
\text { of F-test }\end{array}$ & US & 0.6595 & 0.7829 & 0.7044 & 0.6216 & 0.5177 & 0.4786 & 0.2708 & 0.1533 & 0.0629 & 0.0152 & 0.0480 \\
& UK & 0.0067 & 0.0066 & 0.0198 & 0.0271 & 0.0288 & 0.0444 & 0.0599 & 0.0407 & 0.0329 & 0.0346 & 0.0396 \\
& Canada & 0.0004 & 0.0023 & 0.0037 & 0.0369 & 0.0647 & 0.0180 & 0.0019 & 0.0017 & 0.0053 & 0.0046 & 0.0202 \\
& Germany & 0.1277 & 0.0248 & 0.3545 & 0.2380 & 0.4501 & 0.4804 & 0.5804 & 0.4334 & 0.7282 & 0.6820 & 0.7234 \\
\hline
\end{tabular}

Another common feature of the four CCF graphs is that for $\mathrm{k}<0$, the CCF is strictly increasing. However, for $k \geq 0$, the four graphs differ. For UK and Canada, CCF keeps strictly increasing. This shows that for these two countries, their ShiryaevZhou indices clearly lead their corresponding securitized real estate indices. However, for Germany, the CCF remains nearly constant, so it is unclear whether its Shiryaev-Zhou index leads its corresponding securitized real estate index. For US, $\mathrm{CCF}$ peaks at around $k=0$ and decreases slightly when $\mathrm{k}$ further increases. It is more likely that US's securitized real estate index and its corresponding Shiryaev-Zhou index are positively correlated rather than one index leading the other. This result reveals that for all four countries, if the Shiryaev-Zhou index attains a peak (or trough), the corresponding securitized real estate index will also attains a peak (or trough) sooner or later. In particular, UK and Canada's Shiryaev-Zhou indices are clear leading indicators of their corresponding securitized real estate indices.

Next, we examine the predictive power of the Shiryaev-Zhou on its corresponding securitized real estate index. For each of the four countries, we conduct the Granger causality test against the following null hypothesis:

$\mathrm{H}_{0}$ : the Shiryaev-Zhou does not Granger-cause its corresponding securitized real estate index.

As before, the first 130 observations of each securitized real estate index are removed. Table 2 shows the result preformed by Wessa (2012).

From Table 2, for UK and Canada, the Granger causality test gives $p$-values of $<0.05$ for all cases, except when the number of non-seasonal time lags in test is 7 for UK, and 5 for Canada. In most cases, at $5 \%$ significance level, the null hypothesis $\mathrm{H}_{0}$ is rejected, i.e., there is significant evidence that the Shiryaev-Zhou index Granger-cause its corresponding securitized real estate index. This shows that for UK and Canada, their ShiryaevZhou indices are good predictors of their corresponding securitized real estate indices. However, how US and Germany, the Granger causality test gives $p$-values of $<0.05$ only when the number of non-seasonal time lags in test is 10 or 11 for US, and 2 for Germany. For most cases, at 5\% significance level, the null hypothesis $\mathrm{H}_{0}$ is not rejected, i.e., there is no significant evidence that the Shiryaev-Zhou index Granger-cause its corresponding securitized real estate index. Hence the predictive power of US and Germany's Shiryaev-Zhou indices on their corresponding securitized real estate indices is smaller than that of UK and Canada's Shiryaev-Zhou indices. Comparing the result of Table 2 with Figs 5 to 8, we can see that if the Shiryaev-Zhou index is a clear leading indicator of its corresponding securitized real estate index, then the predicting power of the Shiryaev-Zhou index is stronger.

\section{THE RESULTING RETURN ON BUYING AND SELLING THE INDICES ACCORDING TO THEIR SHIRYAEV-ZHOU INDICES}

Here we construct a trading strategy of the four securitized real estate indices by using their Shiryaev-Zhou indices, compute the return by using this strategy to trade the indices, and compare the result with the return by using the "buy-and-hold" strategy. The Shiryaev-Zhou index of each securitized real estate index on each day is estimated by the method described in Section 3. We make the following assumptions:

1. We start with an infinite amount of money.

2. The transaction price (buying and selling price) is the closing price of that day.

3. There are no transaction costs.

For each of the four indices, we construct a trading strategy as follows:

1. From Day 1 to Day 130 (January 2 to July 2, 1990), do not take any action as the value of $\hat{\mu}_{i}$ is not available yet.

2. On Day 131 (July 3, 1990), if $\hat{\mu}_{i} \geq 0$, buy one unit of the index. Otherwise, do not take any action. 
3. From Day 132 (July 4, 1990) onwards, trade the index according to the following strategy (see Table 3).

Table 3. Our trading strategy from Day 132 onwards

\begin{tabular}{lll}
\hline$\hat{\mu}_{i-1}$ & $\hat{\mu}_{i}$ & Action \\
\hline$\geq 0$ & $\geq 0$ & $\begin{array}{l}\text { No action (keep holding one unit of the } \\
\text { index) }\end{array}$ \\
$\geq 0$ & $<0$ & $\begin{array}{l}\text { Sell the entire one unit of the index we } \\
\text { hold }\end{array}$ \\
$<0$ & $\geq 0$ & Buy one unit of the index \\
$<0$ & $<0$ & No action (keep holding entire cash) \\
\hline
\end{tabular}

4. On the last day of the period (April 28, 2009), sell the entire one unit of the index if one is still holding one unit of the index.

Table 4 shows the resulting return of the securitized real estate indices of the four countries by applying the trading strategy above.

Table 5 shows the resulting return of the securitized real estate indices of the four countries by holding one unit of each index throughout the whole period (i.e. the "buy-and-hold" strategy).

From Tables 4 and 5, we can see that for the securitized real estate indices of UK, Canada and Germany, we can obtain a much greater index return and percentage return by following the trading strategy according to the Shiryaev-Zhou index. If we hold the index throughout the whole period, we would suffer from a loss, but if we follow the strategy according to the Shiryaev-Zhou index, then we can earn a profit, which is much better than the result when we use the "buy-andhold" strategy. The only exception is US's index, of which we can only get a slightly larger index return using the trading strategy according to the Shiryaev-Zhou index, but the percentage return is much lower because we have to buy the index several times, making the total cost much larger. In overall, the trading strategy according to the Shiryaev-Zhou index outperforms the "buy-andhold" strategy.

However, in real life situations, transaction costs do exist. This may affect the results. In the following, we compare the return of the two trading strategies on the four securitized real estate indices. We assume that the transaction cost of buying one unit of each index is equal to $0.5 \%$ of its transaction price, and there are no transaction costs of selling any of the four indices.

The following Tables 6 and 7 show the resulting return of the securitized real estate indices of the four countries by applying the two trading strategies.

Comparing Tables 5 and 6 with Tables 3 and 4, we can see that with the presence of $0.5 \%$ buying cost, the returns by using the "buy-and-hold" strategy decrease slightly only. However, if we use the trading strategy according to the Shiryaev-Zhou index, the returns diminish by a larger extent. For US's securitized real estate index, the "buy-andhold" strategy even outperforms the trading strategy according to the Shiryaev-Zhou index. For the securitized real estate indices of the other three countries, the trading strategy according to the Shiryaev-Zhou index still provides a greater return than the "buy-and-hold" strategy. This is because the "buy-and-hold" strategy requires investors to

Table 4. The return of the securitized real estate indices of the four countries by the trading strategy according to the Shiryaev-Zhou index

\begin{tabular}{lllll}
\hline Countries & US & UK & Canada & Germany \\
\hline Index return & 5.92 & 4559.30 & 1066.74 & 89.01 \\
Percentage return & $0.05 \%$ & $5.75 \%$ & $1.03 \%$ & $0.38 \%$ \\
\hline
\end{tabular}

Table 5. The return of the securitized real estate indices of the four countries by holding one unit of each index throughout the whole period

\begin{tabular}{lllll}
\hline Countries & US & UK & Canada & Germany \\
\hline Index return & 5.88 & -256.25 & -1298.68 & -31.56 \\
Percentage return & $6.74 \%$ & $-13.91 \%$ & $-53.25 \%$ & $-8.88 \%$ \\
\hline
\end{tabular}

Table 6. The return of the securitized real estate indices of the four countries by the trading strategy according to the Shiryaev-Zhou index, with the presence of $0.5 \%$ buying cost

\begin{tabular}{lllll}
\hline Countries & US & UK & Canada & Germany \\
\hline Index return & -54.54 & 4162.93 & 546.46 & -27.45 \\
Percentage return & $-0.45 \%$ & $5.23 \%$ & $0.52 \%$ & $-0.12 \%$ \\
\hline
\end{tabular}


Table 7. The return of the securitized real estate indices of the four countries by holding one unit of each index throughout the whole period, with the presence of $0.5 \%$ buying cost

\begin{tabular}{lllll}
\hline Countries & US & UK & Canada & Germany \\
\hline Index return & 5.44 & -265.46 & -1310.88 & -33.34 \\
Percentage return & $6.21 \%$ & $-14.34 \%$ & $-53.49 \%$ & $-9.33 \%$ \\
\hline
\end{tabular}

Table 8. No. of times of buying the securitized real estate indices of the four countries when applying the strategy according to the Shiryaev-Zhou index

\begin{tabular}{lllll}
\hline Countries & US & UK & Canada & Germany \\
\hline $\begin{array}{l}\text { No. of times of buying } \\
\text { the index }\end{array}$ & 81 & 38 & 84 & 66 \\
\hline
\end{tabular}

purchase and sell the stock/stock index one time only, so the transaction cost is much smaller. However, when we use the trading strategy according to the Shiryaev-Zhou index, we have to purchase and sell the stock/stock index several times. Therefore, the transaction cost accumulates and may even offset the gain. Nevertheless, the trading strategy according to the Shiryaev-Zhou index is still superior on the whole as this strategy yields a greater return than the "buy-and-hold" strategy does, except for US's securitized real estate index.

If we get a closer look at the number of times we buy the securitized real estate indices when we trade them using the strategy we constructed in this paper, we can see why transaction cost diminishes the return when applying this strategy.

From Table 8, we can see that by applying the trading strategy we constructed using the Shiryaev-Zhou index, the number of times of buying U.K.'s securitized real estate index is the least among the four indices (38 times). This is why the presence of transaction cost just reduces the return slightly from 4559.30 to 4162.93 (see Tables 4 and 6). For the other three indices, we have to buy the indices more frequently (66 to 84 times), making the total cost much larger. Hence transaction cost diminishes the return by a larger extent (see Tables 4 and 6). For Canada and Germany's indices, without transaction costs, our strategy outperforms the "buy-and-hold" strategy by a larger extent, so even with $0.5 \%$ buying cost, our strategy is still superior. However, for U.S.'s index, our strategy only yields a slightly larger index return than the "buy-and-hold" strategy does. Hence with $0.5 \%$ buying cost, our strategy is outperformed by the "buy-and-hold" strategy.

Comparing the results of Tables 4 to 7 with Table 2 , we can see a relationship between the Shiryaev-Zhou's predictive power on its corresponding securitized real estate index and the return by applying the corresponding trading strategy in com- parison to the "buy-and-hold" strategy. For UK and Canada, Table 2 shows that the predictive power of their Shiryaev indices on their corresponding securitized real estate indices is stronger. Tables 4 to 7 show that no matter the $0.5 \%$ buying cost exists or not, the trading strategy we constructed using the Shiryaev-Zhou index greatly outperforms the "buy-and-hold" strategy for UK and Canada's securitized real estate indices. On the other hand, US and Germany's Shiryaev indices have a weaker predictive power (see Table 2). From Tables 4 to 7 , our trading strategy just merely beats the "buyand-hold" strategy for Germany's securitized real estate index in the presence of $0.5 \%$ buying cost. For US's securitized real estate index, the return is even worse: without transaction costs our strategy only slightly outperforms the "buy-and-hold" strategy. With $0.5 \%$ buying cost, our strategy even yields a lower return than the "buy-and-hold" strategy. Hence if the Shiryaev-Zhou has a stronger predictive power, the corresponding trading strategy will beat the "buy-and-hold" strategy by a larger extent.

There is still an error in real life situations. Our method use the stock prices from day $i-n+1$ to day $i$ to estimate the Shiryaev-Zhou index $\mu$ on day $i$. Hence our estimated value $\hat{\mu}_{i}$ in fact lags behind the true value $\mu$. If $n$ is larger, then the lagging effect will be greater. However, if $n$ is too small, the error in estimating the drift $\alpha$ and the volatility $\sigma$ will be too large. Therefore, we should choose a suitable moving window size $n$, and it turns out that it is practically effective to choose $n=130$ (Hui et al. 2012).

\section{CONCLUSIONS}

From the above statistics of the Shiryaev-Zhou indices of securitized real estate indices of four countries, a number of conclusions can be drawn. Firstly, the Shiryaev-Zhou indices of securitized real estate indices of the four countries can reflect 
important events which affect the real estate markets. Some of the events are worldwide and affect almost all countries, like the subprime mortgage crisis and the global financial crisis starting from late 2007, which caused the worst global economic recession since World War II. This is reflected by the Shiryaev-Zhou index of securitized real estate indices of most countries, which stayed negative since late 2007. Some events, on the other hand, occur locally and affect a particular country only. For example, in early 1996, an unusually cold winter hit Germany, hitting its economy hard. Thus its Shiryaev-Zhou index struck a historical low at -170 . However, the Shiryaev-Zhou index of securitized real estate indices of most other countries remained relatively stable at that time. The Shiryaev-Zhou index provides convincing signals which truly reflect different/diverse situations and trends in the four countries under investigation.

Secondly, the Shiryaev-Zhou index has some important relationships with its corresponding stock (or stock index). From Section 5, there is a positive (but weak) correlation between the securitized real estate index and its corresponding Shiryaev-Zhou index for all four countries. This shows that each securitized real estate index and its corresponding Shiryaev-Zhou index move in the same direction in general. A further analysis of the $\mathrm{CCF}$ between each securitized real estate index and its corresponding Shiryaev-Zhou index shows that for all four countries, the Shiryaev-Zhou index does not lag behind its corresponding securitized real estate index. In particular, UK and Canada's Shiryaev-Zhou indices are clear leading indicators of their corresponding securitized real estate indices. For these two countries, the Granger causality test shows that their Shiryaev-Zhou indices have a stronger predictive power on their corresponding securitized real estate indices, too. We can see that the Shiryaev-Zhou index is a good predictor of its corresponding stock (or stock index) when the CCF between the stock price (or stock index) is strictly increasing, i.e. the Shiryaev-Zhou is a leading indicator of its corresponding stock (or stock index).

Moreover, the Shiryaev-Zhou index can also provide a strategy for buying and selling stocks as follows: an investor buys a stock as soon as the index turns positive, and holds the stock until the index turns negative, when the investor should sell the stock immediately (as described in Section 5). Our result in Section 6 shows that this strategy generally outperforms the "buy-and-hold" strategy under the assumption of no transaction costs. However, the presence of transaction costs reduces the return substantially when we use the trading strategy according to the Shiryaev-Zhou index. This strategy may even underperform the "buy-and-hold" strategy if the transaction costs are large enough. In our case, this strategy is still superior on the whole even with the presence of $0.5 \%$ buying cost. In real life situations, the transaction costs are relatively small in general, so it is expected that this strategy would outperform the "buy-and-hold" strategy in most cases. Therefore, it is still worthwhile to follow this trading strategy in general. The Shiryaev-Zhou index can help investors to formulate a better trading strategy to increase their profit.

Further analysis shows that the return by applying our trading strategy constructed using the Shiryaev-Zhou index is related to the ShiryaevZhou index's predictive power on its corresponding stock (or stock index). For UK and Canada, where the Granger causality test shows that their Shiryaev-Zhou indices have a stronger predictive power on their corresponding securitized real estate indices, our strategy yields a much larger return than the "buy-and-hold" strategy does. For the other two indices with smaller predictive power, out strategy only merely beats the "buyand-hold" strategy, or, even worse, is outperformed by the "buy-and-hold" strategy, as in the case of US's securitized real estate index with the presence of $0.5 \%$ buying cost. Hence before applying our trading strategy, it is preferable to conduct the Granger causality test first. If the test shows that the Shiryaev-Zhou index is a good predictor of its corresponding stock (or stock index), then our trading strategy is likely to beat the "buy-and-hold" strategy overwhelmingly. Otherwise, our trading strategy may only outperform the "buy-and-hold" strategy by a smaller extent. In the worst case, when the predictive power of the Shiryaev-Zhou is weak and the transaction costs are high, it may be better to stick with the "buy-and-hold" strategy.

In applying our trading strategy, there is still an error which comes from the moving window size $n$ (no. of days in estimating the drift and volatility) we choose, which affects the estimated value $\hat{\mu}_{i}$ of the Shiryaev-Zhou index $\mu$. In the future, one may investigate the effect of choosing different sizes of $n$ on the resulting return on trading the stocks (or stock indices) using the strategy according to the Shiryaev-Zhou indices of the stocks (or stock indices).

To conclude, the Shiryaev-Zhou index can reflect local and worldwide events affecting the economy and serve as a predictor for certain stocks/ 
stock indices. It can also act as a signal for buying and selling a stock. This can help investors to formulate a better buying/selling strategy which can beat the "buy-and-hold" strategy.

\section{ACKNOWLEDGEMENT}

We are grateful for the financial support from the PolyU Internal Research Grants (Project \#GYH86, G-YH96 and Z02Z).

\section{REFERENCES}

Chau, K. W.; Wong, S. K.; Yiu, C. Y.; Leung, H. F. 2005. Real estate price indices in Hong Kong, Journal of Real Estate Literature 13(3): 337-356.

Du Toit, J.; Peskir, G. 2009. Selling a stock at the ultimate maximum, Annals of Applied Probability 19(3): 983-1014. http://dx.doi.org/10.1214/08-AAP566

Graversen, S. E.; Peskir, G.; Shiryaev, A. N. 2001. Stopping Brownian motion without anticipation as close as possible to its ultimate maximum, Theory of Probability and Its Applications 45(1): 41-50. http:// dx.doi.org/10.1137/S0040585X97978075

Hui, E. C. M.; Lau, O. M. F.; Lo, K. K. 2009. A fuzzy decision-making approach for portfolio management with direct real estate investment, International Journal of Strategic Property Management 13(2): 191-204. http://dx.doi.org/10.3846/1648-715X.2009.13.191-204

Hui, E. C. M.; Wong, J. T. Y. 2004. BRE index for the Hong Kong residential property market, International Journal of Strategic Property Management 8(2): 105-119. http://dx.doi.org/10.1080/164871 5X.2004.9637511

Hui, E. C. M.; Yam, S. C. P.; Chen, S. W. 2012. ShiryaevZhou index - a noble approach to benchmarking and analysis of real estate stocks, International Journal of Strategic Property Management 16(2): 158-172. http://dx.doi.org/10.3846/1648715X.2011.638946

Hui, E. C. M.; Zuo, W, J.; Hu, L. 2011. Examining the relationship between real estate and stock markets in Hong Kong and the United Kingdom through data mining, International Journal of Strategic Property Management 15(1): 26-34. http://dx.doi.org/10.3846/ 1648715X.2011.565867

Knight, J.; Lizieri, C.; Satchell, S. 2005. Diversification when it hurts? The joint distributions of real estate and equity markets, Journal of Property Research 22(4): 309-323. http://dx.doi. org/10.1080/09599910600558520

Li, X.; Zhou, X. Y. 2006. Continuous-time meanvariance efficiency: the $80 \%$ rule, Annals of Applied Probability 16(4): 1751-1763. http://dx.doi. org/10.1214/105051606000000349

Liow, K. H. 2006. Dynamic relationship between stock and property markets, Applied Finan- cial Economics 16(5): 371-376. http://dx.doi. org/10.1080/09603100500390885

Markowitz, H. 1952. Portfolio selection, Journal of Finance 7(1): 77-91. http://dx.doi. org/10.1111/j.1540-6261.1952.tb01525.x

Okunev, J.; Wilson, P. J. 1997. Using nonlinear tests to examine integration between real estate and equity markets, Real Estate Economics 25(3): 487-503. http://dx.doi.org/10.1111/1540-6229.00724

Okunev, J.; Wilson, P. J.; Zurbruegg, R. 2000. The causal relationship between real estate and stock markets, Journal of Real Estate Finance and Economics 21(3): 251-261. http://dx.doi.org/10.1023/A:1012051719424

Quan, D. C.; Titman, S. 1999. Do real estate prices and stock prices move together? An international analysis, Real Estate Economics 27(2): 183-207. http:// dx.doi.org/10.1111/1540-6229.00771

Rehring, C.; Sebastian, S. 2011. Dynamics of commercial real estate asset markets, return volatility and the investment horizon, Journal of Property Research 28(4): 291-315. http://dx.doi.org/10.1080/09599916. 2011.596943

Shiryaev, A. N. 2002. Quickest detection problems in the technical analysis of the financial data, in Mathematical Finance - Bachelier Congress, 28 June - 1 July, 2000, Paris, 487-521.

Shiryaev, A. N.; Xu, Z. Q.; Zhou, X. Y. 2008. Thou shalt buy and hold, Quantitative Finance 8(8): 765-776. http://dx.doi.org/10.1080/14697680802563732

Tse, R. Y. C. 2001. Impact of property prices on stock prices in Hong Kong, Review of Pacific Basin Financial Markets and Policies 4(1): 29-43. http://dx.doi. org/10.1142/S0219091501000309

Wessa, P. 2012. Free statistics software, Office for Research Development and Education, version 1.1.23r7. Available at: http://www.wessa.net/

Wong, F. K. W.; Hui, E. C. M. 2005. PolyU BRE Index indicates continuous rise in flat prices despite impact of interest rate hike. Working Paper.

Yam, S. C. P.; Yung, S. P.; Zhou, W. 2008. What is the right time to buy/sell a stock? Working Paper.

Yam, S. C. P.; Yung, S. P.; Zhou, W. 2012. Optimal selling time in stock market over a finite time horizon, Acta Mathematicae Applicatae Sinica (English Series) 28(3): 557-570. http://dx.doi.org/10.1007/ s10255-012-0169-Z

Yam, S. C. P.; Yung, S. P.; Zhou, W. 2009. Two rationales behind the 'buy-and-hold or sell-at-once' strategy, Journal of Applied Probability 46(3): 651-668. http://dx.doi.org/10.1239/jap/1253279844

Yam, S. C. P.; Yung, S. P.; Zhou, W. 2013. A unified 'bang-bang' principle with respect to R-invariant performance benchmarks, Theory of Probability and Its Applications 57(2): 357-366. http://dx.doi. org/10.1137/S0040585X97986035

Zhou, J. 2010. Comovement of international real estate securities returns: a wavelet analysis, Journal of Property Research 27(4): 357-373. http://dx.doi.org/ 10.1080/09599916.2010.517853 